\title{
PENGARUH PROFITABILITAS DAN LEVERAGE TERHADAP NILAI PERUSAHAAN PADA PT. CHITOSE INTERNASIONAL, TBK PERIODE TAHUN 2015-2019
}

\author{
Novita Wulandari ${ }^{1}$, Indri Ayu Tansar ${ }^{2}$, Boy Suzanto ${ }^{3}$ \\ Sekolah Tinggi Ilmu Ekonomi Pasundan, Bandung, ${ }^{1,2,3}$ \\ Email: novitawulan@gmail.com ${ }^{1}$, indri@ stiepas.ac.id $^{2}$, boy@ stiepas.ac.id $^{3}$
}

\begin{abstract}
One of the ways a company can increase capital is through debt or increasing the number of ownership by listing its shares on the capital market. Thus, this study verifies the effect of profitability and leverage on firm value in one of the companies listed on the Indonesia Stock Exchange. The quantitative method uses to determine the magnitude of the effect of profitability and leverage on value during the 2015-2019 period. The results showed that profitability had a positive and significant effect, while leverage had a negative effect on firm value. However, simultaneously profitability and leverage have a significant effect on firm value. The study results indicate that it is necessary to increase sales and pay attention to the amount of debt and the risks caused. When the amount of debt exceeds their capital, investors will hesitate to remember the risks the company has.
\end{abstract}

Keywords: profitability, leverage, firm value.

\begin{abstract}
Abstrak
Salah satu cara yang didapat dilakukan perusahaan untuk menabah modal adalah dengan hutang atau menambah jumlah kepemilikan dengan mencatatkan sahamnya di pasar modal. Untuk itu penelitian ini menverifikasi pengaruh profitabilitas dan leverage terhadap nilai perusahaan pada salah satu perusahaan yang terdaftar pada Bursa Efek Indonesia. Metode kuantitaif digunakan untuk mengetahui besarnya pengaruh profitabilitas dan leverage terhadap nilai selama periode tahun 2015-2019. Hasil penelitian menunjukkan bahwa profitabilitas berpengaruh positif dan signifikan sedangkan leverage berpengaruh negative terhadap nilai perusahaan. Namun demikian secara simultan profitabilitas dan Leverage secara berpengaruh signifikan terhadap nilai perusahaan. Hasil penelitian mengidikasikan bahwa perlu untuk meningkatkan penjualan dan memperhatikan besaran hutang dan risiko yang ditimbulkan, hal ini dikarenakan
\end{abstract}

Bisnis Dan Iptek | Sekolah Tinggi Ilmu Ekonomi Pasundan Bandung 
April, 2020

ketika jumlah hutang melebihi modal sendiri yang dimiliki, maka investor akan ragu mengingat risiko yang di miliki perusahaan.

\section{Kata kunci: profitabilitas, leverage, nilai perusahaan.}

\section{PENDAHULUAN}

Beberapa cara yang ditempuh perusahaan untuk mencari tambahan modal atau dana adalah dengan hutang atau menambah jumlah kepemilikan dengan mencatatkan sahamnya di pasar modal. Pasar modal secara formal sebagai pasar untuk berbagai instrumen keuangan (atau sekuritas) jangka panjang yang bisa diperjualbelikan, baik dalam bentuk hutang maupun modal sendiri, baik yang diterbitkan oleh pemerintah, public authorities maupun perusahaan swasta (Husnan, 2015:3). Perusahaan manufaktur sendiri di Indonesia merupakan sektor industri yang mendominasi perusahaan perusahaan yang terdaftar di Bursa Efek Indonesia (BEI). Banyaknya perusahaan dalam industri dan kondisi perekonomian saat ini telah menciptakan suatu persaingan antar perusahaan. Pentingnya pendirian suatu perusahaan diperlukan untuk meningkatkan kesejahteraan pemiliknya atau pemegang saham, atau memaksimalkan kekayaan pemegang saham melalui peningkatan nilai perusahaan (Martono dan Harjito, 2010).

Nilai perusahaan sangat penting karna dapat mempengaruhi persepsi investor terhadap perusahaan tersebut (Puspita dan Mahfud, 2011). Nilai Perusahaan juga mencerminkan prospek dan harapan akan kemampuan perusahaan tersebut kedepannya. Nilai perusahaan merupakan harga yang bersedia dibayar oleh calon investor yang diartikan sebagai harga pasar atas perusahaan itu sendiri. Menurut Sartono (2010:487) Nilai perusahaan adalah nilai jual sebuah perusahaan sebagai suatu bisnis yang sedang beroperasi. Adanya kelebihan nilai jual diatas nilai likuidasi adalah nilai dari organisasi manajemen yang menjalankan perusahaan itu. Nilai Perusahaan yang tinggi akan diikuti oleh tingginya kemakmuran pemegang saham (Brigham \& Houston, 2013).

Harga saham sendiri selalu mengalami perubahan yang cepat. Fluktuasi harga saham dipengaruhi oleh kekuatan investor dalam permintaan dan penawaran. Harga saham yang tinggi merupakan sinyal bagi investor agar investor mau menanamkan modalnya pada perusahaan tersebut, mengingat latar belakang dari seorang investor adalah menitikberatkan pada harapan mereka terhadap profit perusahaan. Oleh karena itu harga saham mencerminkan nilai dari suatu perusahaan. Jika perusahaan mencapai prestasi yang baik, maka saham perusahaan tersebut akan banyak diminati oleh para investor. Prestasi baik yang dicapai perusahaan dapat dilihat di dalam laporan keuangan yang dipublikasikan oleh perusahaan (emiten). Emiten berkewajiban untuk mempublikasikan laporan 
April, 2020

keuangan pada periode tertentu. Laporan keuangan ini sangat berguna bagi investor dalam proses pengambilan keputusan investasi, seperti menjual, membeli, atau menanam saham.

Nilai Perusahaan dapat dilihat dari Price to Book Value (PBV) yang menggambarkan seberapa besar pasar menghargai nilai buku saham perusahaan. Nilai buku perusahaan (Book Value Share) dapat diukur melalui perbandingan ekuitas saham biasa dan jumlah saham yang beredar (Brigham \& Houston,2013). Untuk menggambarkan Nilai Perusahaan, penulis menyajikan data Nilai Perusahaan (PBV) PT. Chitose Internasional Tbk yang disajikan dalam periode kuartal mengacu pada dasar laporan keuangan yang dirilis oleh emiten itu sendiri dan Bursa Efek Indonesia.

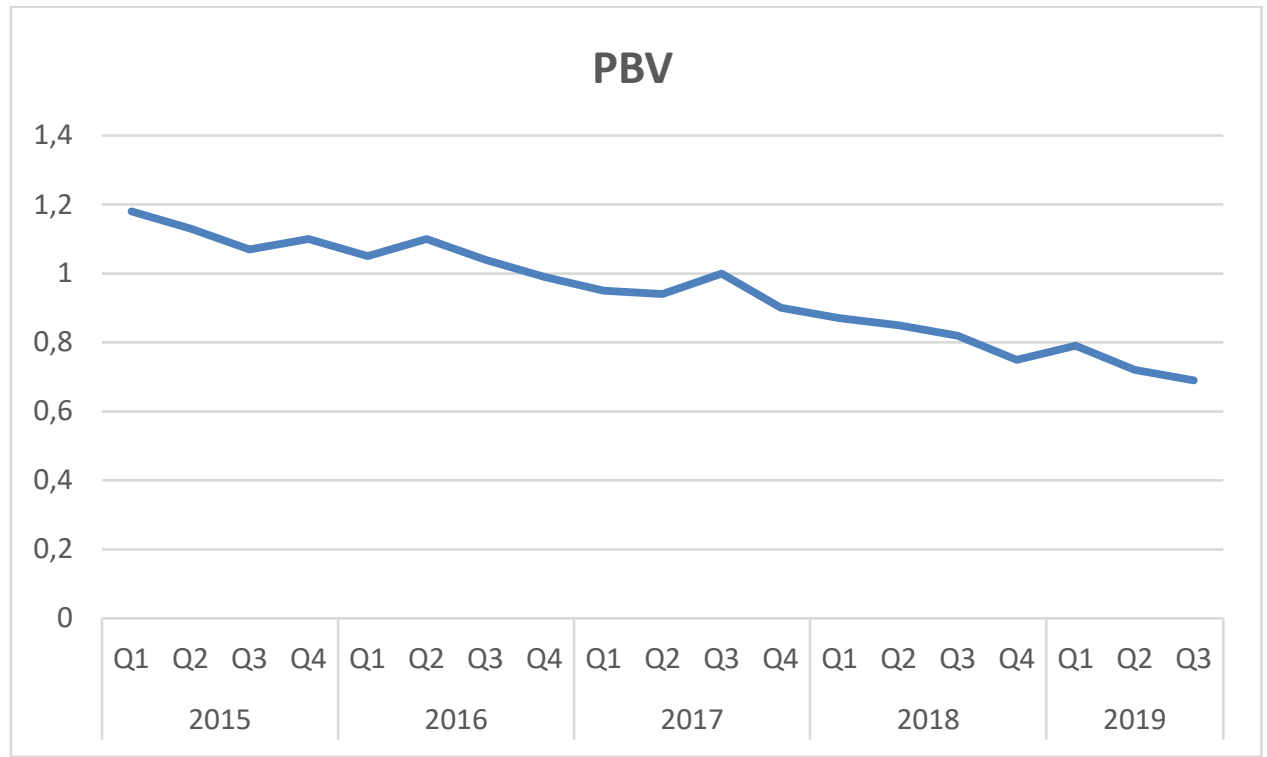

Sumber : Proclick, data diolah

Gambar 1 Nilai Perusahaan (PBV) PT. Chitose Internasional, TBK periode Tahun 2015-2019

Gambar 1 adalah kurva pergerakan Nilai Perusahaan yang diproksikan melalui PBV (Price to Book Value) selama periode 2015 sampai dengan 2019 pada PT Chitose Internasional tbk. Nilai Perusahaan menunjukan penguatan yang signifikan di kuartal pertama 2015, lalu mengalami penurunan hingga akhir kuartal ke-3 2015. Mengalami kenaikan secara bertahap pada kuartal ke-4 2015 hingga kuartal ke-3 2016, selanjutnya mengalami penurunan yang cukup signifikan hingga kuartal ke-3 2017 kemudian mengalami kenaikan di akhir kuartal ke-3 2017 selanjutnya mengalami penurunan yang sangat signifikan hingga kuartal pertama 2019 dan selanjutnya mengalami perubahan yang tidak terlalu signifikan.

Nilai perusahaan dapat dipengaruhi oleh besar kecilnya profitabilitas yang dihasilkan. Profitabilitas merupakan kemampuan perusahaan memperoleh laba dalam hubungannya dengan penjualan, total aktiva maupun modal sendiri. Menurut Kasmir $(2014 ; 196)$ profitabilitas adalah kemampuan perusahaan dalam 
April, 2020

mencari keuntungan. Rasio ini juga memberikan ukuran tingkat efektivitas manajemen perusahaan. Hal ini ditunjukan oleh laba yang dihasilkan dari penjualan dan pendapatan investasi. Intinya dalam penggunaan rasio ini, menunjukan efisiensi perusahaan.

Profitabilitas dapat dinyatakan dalam return on equity (ROE). Return on Equity (ROE) merupakan rasio yang menunjukan kemampuan perusahaan dalam menghasilkan laba bersih untuk pengembalian ekuitas pemegang saham. ROE merupakan rasio keuangan yang digunakan untuk mengukur profitabilitas dari ekuitas. Semakin besar hasil ROE maka kinerja perusahaan semakin baik. Rasio yang meningkat menunjukan bahwa kinerja manajemen meningkat dalam mengelola sumber dana pembiyaan operasional secara efektif untuk menghasilkan laba bersih (profitabilitas meningkat). Jadi dapat dikatakan bahwa selain memperhatikan efektivitas manajemen dalam mengelola investasi yang dimiliki perusahaan, investor juga memperhatikan kinerja manajemen yang mampu mengelola sumber dana pembiayaan secara efektif untuk menciptakan laba bersih. ROE menunjukan keuntungan yang akan dinikmati oleh pemilik saham.

Besarnya rata - rata profitabilitas (Return on Equity) pada PT Chitose Internasional tbk selama periode 2015 - 2019 dapat dilihat dari data berikut ini :

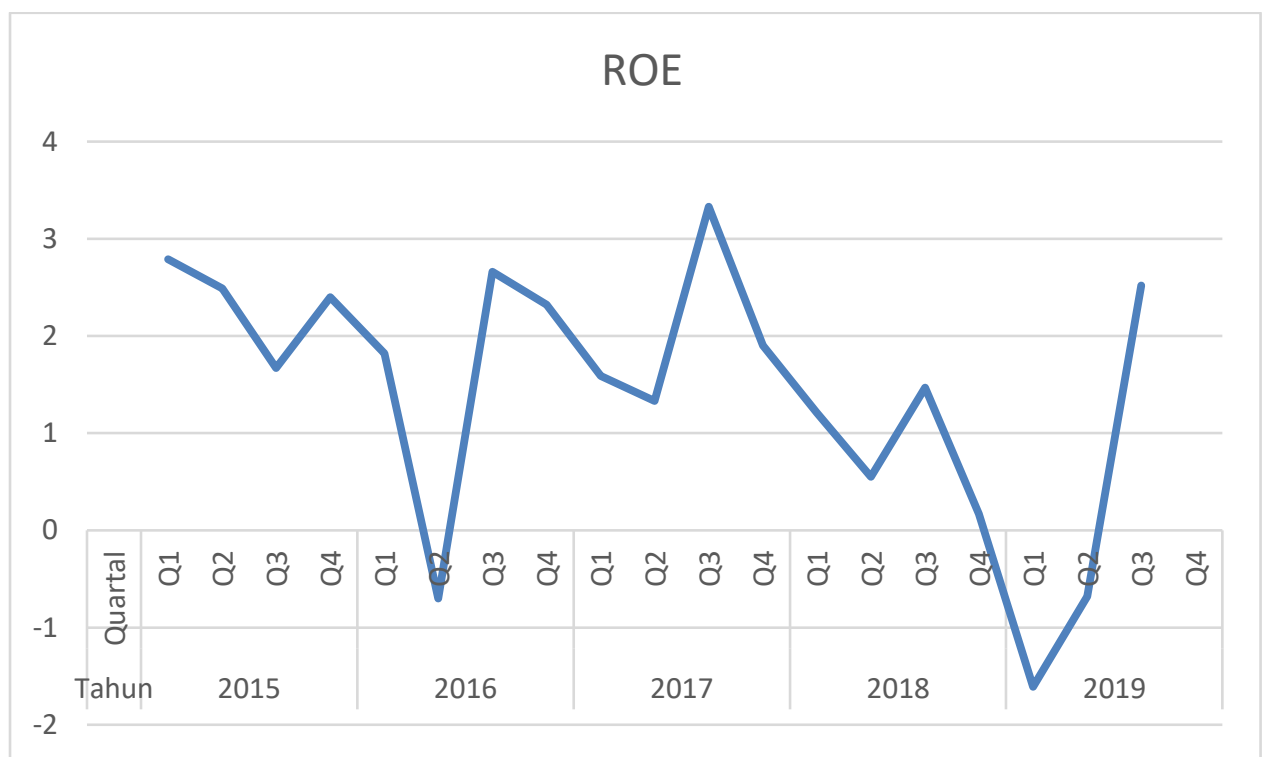

Sumber : Proclick, data diolah

Gambar 2 Profitabilitas (ROE) PT. Chitose Intenasional,TBK periode 2015-2019

Berdasarkan gambar 2 dapat diketahui bahwa terjadi peningkatan dan penurunan besarnya Profitabilitas yang diproksikan dengan ROE selama 2015 - 2019. Profitabilitas menunjukan peningkatan yang tidak terlalu signifikan hingga kuartal petama 2016 kemudian mengalami penurunan dan peningkatan yang signifikan hingga kuartal pertama di tahun 2018, sampai mengalami penurunan yang sangat signifikan hingga kuartal ke - 42019. 
April, 2020

Selain profitabilitas, nilai perusahaan juga dapat dipengaruhi oleh leverage. Leverage perusahaan dapat diukur dengan rasio hutang terhadap total ekuitas. Leverage adalah suatu kebijakan sebuah perusahaan untuk menggunakan dana yang di dapat dari luar perusahaan. Menurut Brigham \& Houston (2013) rasio leverage mengukur tingkat solvabilitas suatu perusahaan. Rasio ini menunjukkan kemampuan suatu perusahaan untuk memenuhi segala kewajiban finansialnya seandainya perusahaan tersebut pada saat itu dilikuidasi. Menurut Sartono (2010:257) leverage adalah penggunaan assets dan sumber dana oleh perusahaan yang memiliki biaya tetap dengan maksud agar meningkatkan keuntungan potensial pemegang saham. Karena kenaikan leverage dapat meningkatkan risiko arus laba bagi pemegang saham biasa, investor dihadapkan pada trade off antara risiko dan hasil pengembalian yang diharapkan. Hasil pengembalian yang tinggi menyebabkan harga saham lebih tinggi sedangkan risiko yang lebih tinggi menyebabkan harga saham lebih rendah. Sehingga naik atau turunnya harga saham dapat berpengaruh pada nilai perusahaan.

Besarnya rata - rata Leverage pada PT Chitose Internasional tbk selama periode 2015 - 2019 dapat dilihat dari data berikut ini :

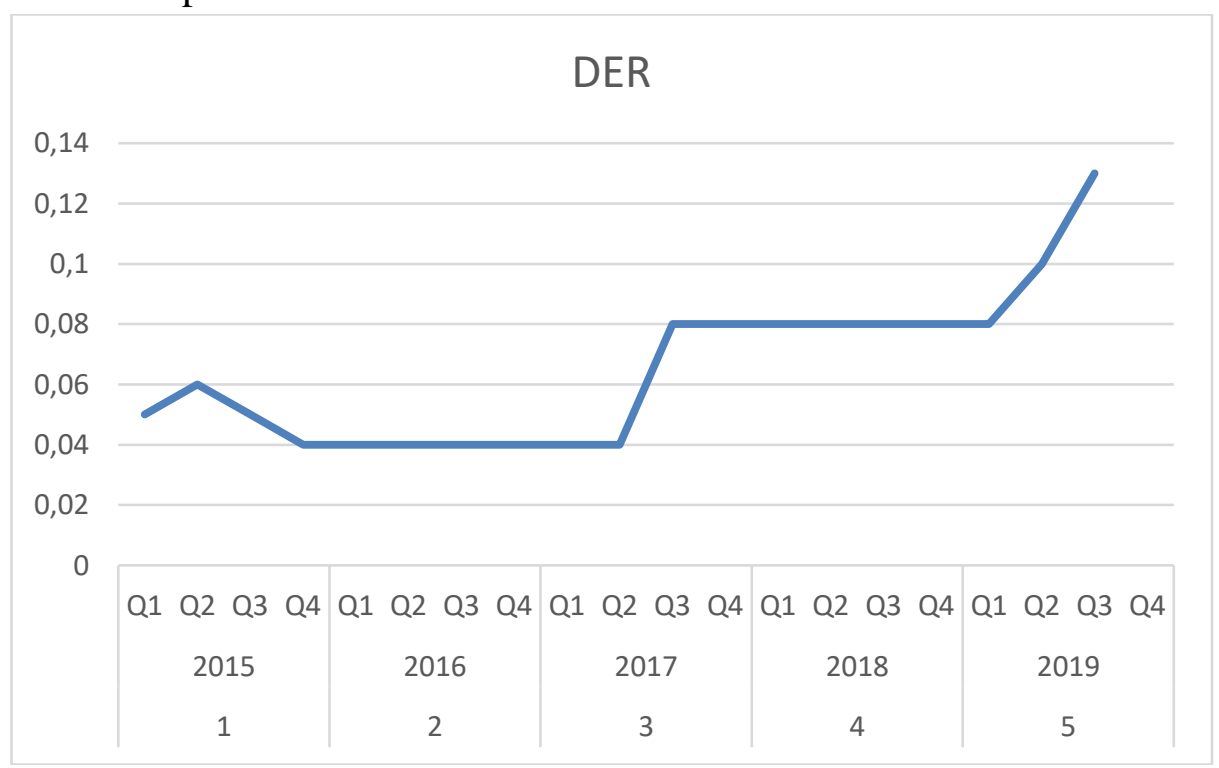

Sumber : Proclick, data diolah

Gambar 3 Rata - rata Debt to Equity Rasio di PT Chitose Internasional tbk tahun 2015 - 2019

Berdasarkan data yang telah disajikan pada gambar 3 dapat diketahui bahwa terjadi peningkatan dan penurunan besarnya Leverage perusahaan yang diproksikan dengan DER selama periode 2015 - 2019 dilihat adanya peningkatan yang signifikan pada kuartal ke-3 2017, selanjutnya leverage stabil hingga kuartal ke-2 2019, dan mengalami peningkatan yang signifikan sampai kuartal ke-4 2019 ini. 
Beberapa penelitian yang berhubungan dengan nilai perusahaan yaitu menurut penelitian Rudangga dan Sudiarta (2016) membuktikan bahwa leverage dan profitabilitas berpengaruh terhadap nilai perusahaan. Hal ini didukung juga dengan penelitian yang dilakukan oleh Dalci (2018) yang membuktikan bahwa leverage dan profitabilitas mempunyai pengaruh signifikan terhadap nilai perusahaan. Berdasarkan uraian yang telah dikemukakan di dalam latar belakang penelitian, maka rumusan masalah pada penelitian ini seberapa besar pengaruh profitabilitas dan leverage terhadap nilai perusahaan baik secara parsial maupun secara simultan. Adapun maksud dari penelitian ini yaitu untuk mengetahui seberapa besar pengaruh profitabilitas terhadap nilai perusahaan dan seberapa besar pengaruh leverage terhadap nilai perusahaan.

\section{KERANGKA PEMIKIRAN}

Nilai perusahaan dapat pula dipengaruhi oleh tingkat profitabilitas yang dihasilkan oleh perusahaan. Profitabilitas adalah kemampuan perusahaan memperoleh laba dalam hubungannya dengan penjualan, total aktiva, maupun modal sendiri. Dengan demikian bagi investor jangka panjang akan sangat berkepentingan dengan analisis profitabilitas ini. Misalnya bagi pemegang saham akan melihat keuntungan yang benar-benar akan diterima dalam bentuk dividen. (Sartono:2012). Menurut Sujoko dan Subiantoro dalam Nugraha et al, (2018) Perusahaan yang memiliki tingkat profitabilitas yang tinggi akan diminati sahamnya oleh investor unntuk menanamkan modalnya di emiten tersebut, tingginya minat investor untuk menanamkan modal pada emiten dengan ROE yang tinggi akan meningkatkan nilai perusahaan melalui peningkatan harga sahamnya di Pasar Modal.

Pada penelitian yang dilakukan oleh Novari dan Lestari (2016) dengan judul pengaruh ukuran perusahaan, leverage, dan profitabilitas terhadap nilai perusahaan pada sektor properti dan real estate mengemukakan bahwa profitabilitas berpengaruh positif dan signifikan pada nilai perusahaan. Arah positif tersebut memiliki arti bahwa semakin besar profitabilitas maka nilai perusahaan yang diperoleh juga semakin besar. Perusahaan yang memiliki profitabilitas yang cukup tinggi akan mendapatkan dana yang cukup, sehingga perusahaan dapat meningkatkan kinerjanya yang berakibat pada meningkatnya nilai perusahaan. perusahaan meningkatkan laba, maka nilai perusahaan akan naik yang terlihat dari kenaikan harga sahamnya. Berdasarkan uraian tersebut maka dapat ditarik indikasi awal bahwa profitabilitas mempengaruhi nilai perusahaan.

Menurut Sartono (2010;257) Leverage adalah penggunaan aset dan sumber dana oleh perusahaan yang memiliki biaya tetap dengan maksud agar meningkatkan 
April, 2020

keuntungan potensial pemegang saham. Leverage menjadi penting bagi investor dalam membuat keputusan investasi karena dapat mempengaruhi kemampuan perusahaan untuk memberikan pengembalian kepada pemegang saham (Brigham \& Houston, 2013). Perusahaan yang dapat mengelola leverage dengan baik dapat meningkatkan kepercayaan investor sehingga dapat meningkatkan nilai perusahaan.

Menurut Hanafi (2011:316) Leverage suatu rasio yang mengukur seberapa besar perusahaan dibiayai oleh hutang. Tingkat hutang yang terlalu besar akan memberikan dampak negative pada bilai perusahaan. Adapun penelitian sebelumnya Dang, Vu, Ngo \& Hoang (2019) menemukan bahwa leverage berpengaruh signifikan terhadap nilai perusahaan, penilitian yang dilakukan oleh Zuhroh (2019) yang menyatakan bahwa leverage berpengaruh negatif signifikan terhadap nilai perusahaan.

\section{METODE PENELITIAN}

Tujuan studi dari penelitian ini adalah verifikatif. Sifat dari penelitian verifikatif yaitu untuk menguji kebenaran dari suatu hipotesis yang dilaksanakan melalui pengumpulan data lapangan, dimana dalam penelitian ini diuji pengaruh Profitabilitas Perusahaan dan Leverage Perusahaan terhadap Nilai Perusahaan baik secara parsial maupun secara simultan.

Perusahaan yang dijadikan sample adalah PT Chitose Internasional, Tbk periode tahun 2015 sampai dengan tahun 2019. PT Chitose Internasional, Tbk digunakan dalam penelitian ini karena beberapa alasan, Industri manufaktur merupakan industri yang mendominasi perusahaan perusahaan yang terdaftar di Bursa Efek Indonesia (BEI), Perkembangan penjualan PT Chitose Internasional, Tbk sedang pesat pesatnya dilihat dari banyaknya produksi produk produk baru. Industri ini memiliki cakupan usaha yang luas sehingga dengan berkembangnya PT Chitose Internasional, Tbk ini, akan memberikan dampak yang positif terhadap pertumbuhan ekonomi.

Adapun operasional variable yang digunakan dalam penelitian ini adalah sebagai variable bebas / Independent Variabel yaitu Profitabilitas dengan proxy Return on Equity (ROE) dan Leverage dengan proxy Debt Equity Rasio (DER). Sedangkan Variable terikat / Dependent variable (Y) yang digunakan dalam penelitian ini adalah Nilai Perusahaan. Nilai perusahaan dapat diukur dengan PBV (Price to Book Value). 
Mengacu pada rumusan masalah dan tujuan penelitian yang telah dideskripsikan sebelumnya dalam pendahuluan, maka analisis data dalam penelitian ini menggunakan dua pendekatan analisis data, yaitu analisis verifikatif. Analisis verifikatif dalam penelitian ini digunakan untuk mengetahui besarnya pengaruh dari masing-mamsing variable bebas yaitu profitabilitas dan leverage terhadap variable terikatnya yaitu nilai perusahaan. Adapun metode yang digunakan menggunakan analisis regresi linear berganda. Sebelum dilakukan analisis verifikatif menggunakan metode regresi linear berganda, data penelitian terlebih dahulu harus melewati pengujian asumsi klasik. Adapun pengujian tersebut bertujuan untuk mendapatkan data penelitian yang Best Linear Unbiased Estimator (BLUE). Pengujian tersebut penting dilakukan untuk mendapatkan hasil pengujian regresi linear berganda yang baik.

\section{HASIL DAN PEMBAHASAN}

Sebelum dianalisis terlebih dahulu dilakukan pengujian asumsi klasik. Hasil Uji Normalitas dapat dilihat bahwa grafik histogram memberikan pola distribusi yang melenceng ke kanan, selain itu sebagian besar bar/batang berada di bawah kurva yng berarti bahwa histogram dari nilai perusahaan berdistribusi normal. Berdasarkan gambar P-Plot terlihat titik-titik mengikuti dan mendekati garis diagonalnya, sehingga dapat disimpulkan bahwa data berdistribusi normal. Selain dengan uji histogram dan juga P-Plot, untuk lebih meyakinkan maka perlu dilakukan pengujian statistik melalui Uji One-Sample Kolmogorov-Smirnov Test (uji K-S). Dari hasil pengujian uji K-S, Asymp.Sig. (2-tailed)" nilai dari data unstandardized residual menunjukan angka 0,200 yang artinya lebih besar dari 0,05 menunjukan bahwa uji K-S telah terpenuhi yang artinya data berdistribusi normal.

Hasil Pengujian AutoKorelasi dapat dilihat bahwa nilai Durbin-Watson (DW hitung) sebesar 1,151. Berdasarkan kriteria yang telah ditentukan DW Hitung berada diantara -2 dan 2 , yakni $-2 \leq 0 \leq 2$ maka ini berarti tidak terjadi autokorelasi. Sehingga dapat disimpulkan bahwa Uji Autokorelasi terpenuhi. Hasil Pengujian Multikolinearitas didapatkan bahwa nilai Tolerance pada variabel profitabilitas dan leverage menunjukan angka Tolerance $>0,10$ dan semua nilai dari Variance Inflation Factor (VIF) $<10$ ini menunjukan bahwa tidak terjadi multikuleniaritas. Dan dapat disimpulkan bahwa Uji Multikueniaritas terpenuhi. Hasil pengujian heteroskedastisitas diketahui bahwa tidak terjadi heteroskedastisitas, hal ini karena tidak ada pola yang jelas serta titik-titik menyebar diatas dan dibawah angkanya 0 pada sumbu Y. Sehingga dapat dikatakan bahwa Uji Heteroskedastisitas terpenuhi.

Berdasarkan hasil perhitungan didapatkan persamaan regresi linear sebagai berikut :

Nilai Perusahaan $(\mathrm{PBV})=113,335+3,906 \mathrm{ROE}-3,716 \mathrm{DER}+\varepsilon$ 
April, 2020

Rumusan hasil perhitungan analisis regresi linear berganda tersebut dapat dijelaskan sebagai berikut:

1. Nilai konstanta dalam persamaan regresi linear berganda sebesar 113,335 menunjukan nilai matematis Nilai Perusahaan (PBV) Pada kondisi dimana Profitabilitas (ROE) dan Leverage (DER) bernilai nol.

2. koefisiensi regresi Profitabilitas (ROE) adalah sebesar 3,906 yang berartiapabila Profitabilitas (ROE) mengalami kenaikan sebesar $1 \%$ maka Nilai perusahaan (PBV) akan meningkat sebesar3,906\% dengan asumsi bahwa variabel lain dianggap konstan (ceterus paribus).

3. Koefisien regresi Leverage (DER) adalah sebesar - 3,716 yang berarti apabila Leverage (DER) mengalami kenaikan sebesar 1\%, maka Nilai Perusahaan (PBV) akan turun sebesar 3,716\% dengan asumsi bahwa variabel lain dianggap konstan (ceterus paribus)

Berdasarkan hasil $\mathrm{R}$ squares diketahui bahwa hasil perhitungan pengujian koefisien determinasi $\left(\mathrm{R}^{2}\right)$ didapat nilai $\mathrm{R}$-square sebesar 0,731 atau 73,1\%. Artinya Profitabilitas (ROE) dan Leverage (DER) mempunyai pengaruh sebesar $73,1 \%$ terhadap Nilai Perusahaan (PBV) sedangkan sisanya 26,9\% dipengaruhi oleh variabel-variabel lain yang tidak diteliti.

Dari hasil pengujian secara simultan (Uji F) menunjukan bahwa nilai yang diperoleh dari perbandingan $\mathrm{F}$ hitung dengan $\mathrm{F}$ tabel adalah $\mathrm{F}$ hitung 23,122 > F tabel 3,55 pada tingkat kekeliruan 5\% berarti hasil untuk hipotesisnya adalah Ho ditolak dan $\mathrm{Ha}$ diterima, Artinya dengan tingkat kepercayaan 95\% dapat disimpulkan bahwa Profitabilitas (ROE) dan Leverage (DER) secara bersamasama atau secara simultan berpengaruh signifikan terhadap Nilai Perusahaan (PBV). Selain itu dengan cara melihat hasil tingkat Signifikan yang diperoleh dari tingkat signifikasi yang diperoleh dari tingkat signifikasi Uji F sebesar 0,000 < 0,05 dan keputusan yang diambil dengan tingkat signifikasi untuk hasil hipotesisnya adalah Ho ditolak dan Ha diterima. Artinya Profitabilitas (ROE) dan Leverage (DER) secara bersama-sama berpengaruh signifikan terhadap Nilai Perusahan (PBV).

Hasil yang menyatakan adanya pengaruh signifikan antara Profitabilitas dan Leverage terhadap Nilai Perusahaan juga sejalan dengan penelitian-penelitian yang dilakukan sebelumnya. Diantaranya penelitian yang dilakukan oleh ; Dalci (2018); Alarussi \& Alhaderi, (2018); Nguyen, Nguyen, Tran \& Nghiem (2019) yang menemukan bahwa Profitabilitas dan Leverage secara bersama-sama berpengaruh terhadap Nilai Perusahaan 
April, 2020

\section{KESIMPULAN}

Berdasarkan pada pembahasan yang telah dilakukan, maka dalam penelitian ini dapat disimpulkan Profitabilitas berpengaruh positif dan signifikan. Penelitian ini menunjukan bahwa disaat terjadi kenaikan laba maka harga saham juga ikut naik, sehingga meningkatkan Nilai Perusahaan. ROE merupakan salah satu cerminan perusahaan dihadapan para investor terhadap prospek bagi perusahaan di masa yang akan datang. Semakin tinggi nilai ROE maka akan semakin tinggi nilai perusahaan yang merupakan cerminan terhadap kinerja perusahaan terhadap pengelolaan sumber daya yang dimiliki. Leverage berpengaruh negative dan signifikan terhadap nilai perusahaan. Penelitian ini menunjukan bahwa pada saat Leverage menurun maka disaat itu pula Nilai Perusahaan mengalami kenaikan. Dapat disimpulkan bahwa jumlah hutang lebih besar dibandingkan modal sendiri menyebabkan Leverage melewati titik optimalnya. Hal ini meyebabkan Leverage berpengaruh negative terhadap Nilai Perusahaan. Profitabilitas dan Leverage secara simultan berpengaruh signifikan terhadap Nilai. Penelitian ini menunjukan bahwa pada saat Profitabilitas meningkat dan Leverage menurun pada saat itunpula Nilai Perusahaan mengalami kenaikan.

Untuk kedepannya perusahaan diharapkan dapat meningkatkan profitabilitas, hal ini dikarenakan profitabilitas berpengaruh positif terhadap nilai perusahaan. Dalam peningkatan profitabilitas maka secara idak langsung nilai perusahaan pun akan meningkat. Perusahaan perlu memperhatikan jumlah hutang yang dimiliki perusahaan, ketika jumlah hutang melebihi modal sendiri maka akan menyebabkan leverage mengalami kenaikan. Hal ini dikarenakan Leverage berpengaruh secara negaif, yang artinya ketika terjadi kenaikan leverage maka akan berakibat pada penurunan nilai perusahaan.

\section{REFERENSI}

Alarussi, A. S., \& Alhaderi, S. M. (2018). Factors affecting profitability in Malaysia. Journal of Economic Studies, 45(3), 442458. https://doi.org/10.1108/JES-05-2017-0124

Brigham, F. E., \& Houston, J. F. (2013). Dasar-dasar Manajemen. Keuangan. Jakarta: Salemba Empat.

Dalci, I. (2018). Impact of financial leverage on profitability of listed manufacturing firms in China. Pacific Accounting Review, 30(4), 410432. https://doi.org/10.1108/PAR-01-2018-0008

Dang, H. N., Vu, V. T. T., Ngo, X. T., \& Hoang, H. T. V. (2019). Study the impact of growth, firm size, capital structure, and profitability on enterprise value: Evidence of enterprises in Vietnam. Journal of Corporate Accounting \& Finance, 30(1), 144-160. 
April, 2020

Hanafi, M, M. (2011). Manajemen Keuangan. Yogyakarta: BPFE.

Husnan, S., \& Pudjiastuti, E. (2015), Dasar-Dasar Manajemen Keuangan. Edisi Ketujuh. Yogyakarta: UPP STIM YKPN.

Kasmir. (2014). Analisis Laporan Keuangan, Edisi Pertama, Cetakan Ketujuh. Jakarta: PT. Rajagrafindo Persada.

Martono \& Harjito, A. (2010). Manajemen Keuangan (Edisi 3). Yogyakarta: Ekonisia.

Nguyen, V., Nguyen, T., Tran, T., \& Nghiem, T. (2019). The impact of financial leverage on the profitability of real estate companies: A study from Vietnam stock exchange. Management Science Letters, 9(13), 2315-2326.

Nugraha, A. S., Yusup, M., \& Juhara, D. (2018). Pengaruh Pertumbuhan Perusahaan Dan Profitabilitas Terhadap Nilai Perusahaan Pada Perusahaan Sektor Property Yang Terdaftar Di Bursa Efek Indonesia Periode 20122016. Majalah Bisnis Dan IPTEK, 11(2), 146-165.

Novari, P. M., \& Lestari, P. V. (2016). Pengaruh ukuran perusahaan, leverage, dan profitabilitas terhadap nilai perusahaan pada sektor properti dan real estate. E-Jurnal Manajemen Universitas Udayana, 5(9), 5671-5694.

Puspita, N. S., \& Mahfud, M. K. (2011). Analisis Pengaruh Struktur Modal, Pertumbuhan Perusahaan, Ukuran Perusahaan, dan Profitabilitas Terhadap Nilai Perusahaan Pada Perusahaan Manufaktur Yang Terdaftar Di Bursa Efek Indonesia Periode 2007-2009 (Studi Kasus Pada Sektor Industri Food And Beverages) (Doctoral dissertation, Universitas Diponegoro).

Rudangga, I. G. N. G., \& Sudiarta, G. M. (2016). Pengaruh ukuran perusahaan, leverage, dan profitabilitas terhadap nilai perusahaan. E-Jurnal Manajemen Universitas Udayana, 5(7), 4394-4422.

Sartono, A. (2010). Menejemen Keuangan Teori dan Aplikasi. Edisi 4. BPFE. Yogyakarta.

Zuhroh, I. (2019). The Effects of Liquidity, Firm Size, and Profitability on the Firm Value with Mediating Leverage. KnE Social Sciences, 203-230. 